\title{
Pengaruh Motivasi, Promosi, dan Kepuasan Kerja Terhadap Kinerja Pegawai di Lingkungan Dinas Kesehatan Kabupaten Aceh Tamiang
}

\author{
Cut Imelda \\ Program Studi Magister Manajemen, Universitas Muhammadiyah Sumatera Utara Medan, Indonesia \\ Jl. Denai No. 217, Tegal Sari Mandala II, Medan Denai, Kota Medan, Sumatera Utara 20371 \\ Email: cutmemel2178@gmail.com
}

\begin{abstract}
Abstrak. Penelitian ini bertujuan untuk mengetahui dan menganalisis pengaruh Motivasi, Promosi, dan Kepuasan kerja terhadap kinerja pegawai di lingkungan Dinas Kesehatan Kabupaten Aceh Tamiang. Penelitian ini termasuk pada penelitian kuantitatif sebab pendekatan yang digunakan untuk usulan penelitian, proses, hipotesis, turun ke lapangan, analisis data, kesimpulan data sampai dengan penulisannya menggunakan aspek pengukuran, perhitungan, rumus dan kepastian data numerik. Subyek penelitian adalah pegawai Dinas Kesehatan Kabupaten Aceh Tamiang. Tehnik pengumpulan dengan dilakukan dengan menggunakan kuesioner yang diberikan skor nilai Skala Likert. Data dianalisa menggunakan rumus regresi linear berganda dan uji hipotesis. Hasil penelitian menunjukkan bahwa secara serempakdiketahui bahwa secara parsial motivasi berpengaruh signifikan terhadap kinerja pegawai Dinas Kesehatan Kabupaten Aceh Tamiang. Sedangkan promosi dan kepuasan kerja berpengaruh tidak berpengaruh signifikan terhadap kinerja pegawai Dinas Kesehatan Kabupaten Aceh Tamiang. Secara simultan, motivasi, promosi, dan kepuasan kerja berpengaruh signifikan terhadap kinerja pegawai Dinas Kesehatan Kabupaten Aceh Tamiang.
\end{abstract}

Kata kunci: Motivasi, Promosi Kepuasan Kerja, Kinerja

\begin{abstract}
This study aims to determine and analyze the effect of motivation, promotion, and job satisfaction on employee performance in the Health Office of Aceh Tamiang Regency. This research is included in quantitative research because the approach used for research proposals, processes, hypotheses, down to the field, data analysis, data conclusions to the writing uses aspects of measurement, calculation, formula and certainty of numerical data. The research subjects were employees of the Dinas Kesehatan office in Aceh Tamiang Regency. The collection technique is done by using a questionnaire that is given a Likert Scale score. Data were analyzed using multiple linear regression formulas and hypothesis testing. The results showed that simultaneously it was known that partially motivation had a significant effect on the performance of Aceh Tamiang District Health Office employees. Whereas promotion and job satisfaction had no significant effect on the performance of employees Dinas Kesehatan Office Aceh Tamiang Regency. Simultaneously, motivation, promotion, and job satisfaction significantly effect the performance of employees of the Dinas Kesehatan office in Aceh Tamiang Regency.
\end{abstract}

Keywords : Motivation, Promotion, Job Satisfaction, Performance

\section{PENDAHULUAN}

Sumber daya manusia adalah salah satu asset yang sangat penting dalam lembaga, yang sekaligus juga merupakan mitra lembaga dalam menjalankan aktivitas lembaga karena mereka yang menghasilkan dan melaksanakan pekerjaan. Menurut Suradinata (1996) untuk menghadapi tuntutan masyarakat tersebut maka manajemen pemerintahan harus lebih meningkatkan dan menggerakkan sumber daya manusia yang ada pada unit-unit organisasi pemerintah secara professional dalam memberi pelayanan. Sumber daya manusia merupakan suatu aspek yang sangat penting bagi keberlangsungan hidup dan perkembangan organisasi. 
Sumber daya manusia berguna dalam penguasaan teknologi, menggunakan modal, mengatur dana, dan menghasilkan produk yang berkualitas. Seberapa canggih teknologi yang dimanfaatkan oleh organisasi dalam menjalankan pekerjaan sangat ditentukan oleh kualitas sumber daya manusia yang mengoperasikannya.

Aparatur Sipil Negara (ASN) sebagai unsur utama sumber daya manusia aparatur negara mempunyai peranan penting dalam menentukan keberhasilan penyelenggaraan pemerintahan dan pembangunan. Oleh karena itu tidak dapat dipungkiri bahwa faktor manusia merupakan modal utama yang perlu diperhatikan.dalam suatu pemerintahan. Hal tersebut sangatlah penting karena bagaimanapun keberhasilan suatu organisasi dalam mencapai tujuan ditentukan oleh kualitas dan kemampuan sumber daya manusia.

Dinas Kesehatan kabupaten Aceh tamiang mempunyai Visi Pembangunan yaitu terwujudnya pelayanan kesehatan berkualitas, merata, menuju masyarakat sehat dan mandiri. Visi ini mengandung makna tugas dan fungsi yang diemban Dinas kesehatan untuk pelayanan (to serve) serta selalu melakukan perbaikan pemenuhan kebutuhan secara benar pada seluruh lapisan masyarakat dalam rangka mewujudkan masyarakat sehat fisik dan mental dengan melibatkan peran aktif masyarakat. Menurut Moeheriono (2014) kinerja atau performance merupakan gambaran mengenai tingkat pencapaian pelaksanaan suatu program kegiatan atau kebijakan dalam mewujudkan sasaran, tujuan, visi dan misi organisasi yang dituangkan melalui perencanaan strategis suatu organisasi.

Disetiap pekerjaan pasti ada yang dinamakan kejenuhan dalam bekerja. Pada Dinas Kesehatan ini contohnya, masih banyak pegawai yang bermalas-malasan pada saat jam kerja. Banyak juga yang tidak tahu apa yang menjadi kewajibannya yang sesuai dengan peraturan yang telah disepakati bersama. Peraturan yang diterapkan di Dinas Kesehatan Kabupaten Aceh Tamiang sudah sangat baik. Salah satunya dimulai dari Rapat Bulanan yang dilaksanakan setiap bulan mulai pukul 08.30 sampai dengan jam 17.00 WIB. Rapat Bulanan selain untuk mempererat tali silahturam di Dinas Kesehatan, juga sangat bermanfaat untuk kinerja pegawai. Disamping memberikan motivasi, juga memberikan semua informasi yang dibutuhkan karyawan dalam melaksanakan tugas dan kewajibannya. Rapat bulanan juga membahas keluhan dan kesulitan yang dialami pegawai selama bekerja, dan jika terdapat masalah akan dibahas langsung dan dimusyawarahkan bersama. Namun demikian, masih banyak karyawan yang tidk mengikuti Rapat bulanan dengan berbagai macam alasan.Sementara itu,belum ada sanksi dan hukuman yang tegas yang diberikan pimpinan tentang pegawai yang tidak mengikutinya. Setiap perusahaan ataupun Organisasi mempunyai target pencapaian yang harus dicapai oleh semua pegawainya. Begitu juga dengan Dinas Kesehatan Kabupaten Aceh Tamiang. Motivasi di Dinas Kesehatan ini sangat kuat terbukti dengan target yang harus dicapai setiap pegawainya terutama di Dinas Kesehatan Kabupaten Aceh Tamiang. Setiap atau organisasi menginginkan pegawai yang dapat bekerja mencapai target.karena dengan begitu, Dinas Kesehatan Kabupaten Aceh Tamiang bisa berkembang dan maju.

Kesuksesan Dinas Kesehatan Kabupaten Aceh Tamiang juga membuat kesuksesan setiap pegawai. Pegawai jaman sekarang kebanyakan merasa pimpinan terlalu kejam dalam memberikan tanggung jawab kepadanya. Pegawai merasa apa yang mereka lakukan akan hanya membuat pimpinan dan organisasi maju dan tidak berpengaruh apa-apa terhadap dirinya. Penilaian seperti itu salah besar. Pada Dinas Kesehatan Kabupaten Aceh Tamiang selalu mensupport semua kegiatan karyawan atau pegawainya dalam pencapaian target yang ditetapkan. Pegawai yang berhasil mencapai targetnya akan diberikan konpensasi dan penghargaan yang setimpal. Namun demikian, masih banyak pegawai yang terlena dengan kemalasannya dan lupa akan target pekerjaannya sehingga banyak pegawai yang tidak mencapai targetnya. Hal ini menjadikan pimpinan harus ekstra memberikan pengarahan dan 
motivasi agar pegawai mampu melaksanakan kinerjanya dengan baik. Motivasi adalah suatu faktor yang mendorong seseorang untuk melakukan suatu aktifitas tertentu_menurut (Sutrisno, 2012) sangat penting untuk memberikan situasi yang kondusif dilingkungan organisasi, sehingga akan menambah semangat karyawan atau pegawai dalam meningkatkan kinerja. Pegawai Dinas Kesehatan Kabupaten Aceh Tamiang masih banyak yang belum mengerti akan tanggung jawab dalam pekerjaan serta informasi yang harus disampaikan kepada masyarakat.Informasi yang seharusnya diberikan kepada masyarakat harus jelas dan dipahami. Contohnya informasi tentang imunisasi yang baik. Pegawai harus lebih mengerti dan memahami tentang hal itu. Namun masih banyak pegawai belum paham dan tidak mau menyampaikan informasi kepada masyarakat.

Selain motivasi, kualitas ASN juga dapat ditingkatkan melalui promosi jabatan. Pelaksanaan promosi jabatan dimaksudkan untuk meningkatkan motivasi kerja pegawai agar mau bekerja dengan perilaku kerja yang baik guna meningkatkan produktivitas kerja dan menjamin keberhasilan lembaga tersebut dalam mencapai sasarannya, dengan menyeimbangkan antara faktor individu dan faktor organisasi yang menjadi tempat bagi pegawai tersebut bernaung dan bekerja. Masalah promosi jabatan tidak lepas dari perhatian seorang pimpinan atau atasan. Seorang pemimpin dapat memberikan penghargaan untuk pelaksanaan kerja yang baik bahkan lebih baik dari sebelumnya dengan kenaikan jabatan, karena dengan adanya promosi jabatan yang di berikan seorang pimpinan atau atasan berhubungan erat dengan keberhasilan seseorang,organisasi atau masyarakat dalam mencapai tujuannya.

Menurut Hasibuan (2014) mengatakan bahwa promosi adalah perpindahan yang memperbesar authority dan responsibility karyawan kejahatan yang lebih baik tinggi di dalan satu organisasi sehingga kewajiban,hak,status, dan penghasilannya semakin besar. Selain itu, pegawai yang merasakan kepuasan kerja juga dapat meningkatkan kinerjanya. Banyak faktor yang mempengaruhi kepuasan kerja karyawan, diantaranya adalah kesesuaian pekerjaan kebijaksanaan organisasi termasuk kesempatan untuk berkembang, lingkungan kerja dan perilaku atasan. Menurut Robbins \& Judge (2008) bahwa kepuasan kerja sebagai suatu sikap umum seorang individu terhadap pekerjaannya..

Kinerja dalam sebuah organisasi merupakan salah satu unsur yang tidak dapat dipisahkan dalam suatu lembaga pemerintahan. Kinerja merupakan hasil kerja secara kualitas dan kuantitas yang dapat dicapai oleh seorang pegawai dalam melaksanakan tugas sesuai dengan tanggung jawab yang diberikan kepadanya (Arianty, Bahagia, Lubis, \& Siswadi, 2016). Hal tersebut dijelaskan oleh (Tika, 2014), kinerja sebagai hasil-hasil fungsi pekerjaan/kegiatan seseorang atau kelompok dalam suatu organisasi yang dipengaruhi oleh berbagai faktor untuk mencapai tujuan organisasi dalam periode waktu tertentu.

\section{LANDASAN TEORI Kinerja}

Kinerja suatu organisasi sangat penting,oleh karena itu dengan adanya kinerja maka tingkat pencapaian hasil akan terlihat sehingga akan dapat diketahui seberapa jauh pula tugas yang telah dipikul melalui tugas dan wewenang yang diberikan dapat dilaksanakan secara nyata dan maksimal. Menurut (Moeheriono, 2014) mengemukan bahwa, kinerja atau performance merupakan gambaran mengenai tingkat pencapaian pelaksanaan suatu program kegiatan atau kebijakan dalam mewujudkan sasaran, tujuan, visi organisasi yang dituangkan melalui perencanaan strategis suatu organisasi. Wirawan, (2009) menyebutkan bahwa kinerja adalah keluaran yang dihasilkan oleh fungsi-fungsi atau indikator-indikator suatu pekerjaan atau suatu profesi dalam waktu tertentu. (Mangkunegara, 2017), kinerja adalah hasil kerja secara kualitas 
dan kuantitas yang dicapai oleh seorang pegawai dalam melaksanakan tugasnya sesuai dengan tanggung jawab yang diberikan kepadanya. Sedangkan menurut (Wibowo, 2013) menyebutkan bahwa "Kinerja berasal dari kata performance yang berarti hasil pekerjaan atau prestasi kerja. Namun perlu dipahami bahwa kinerja itu bukan sekedar hasil pekerjaan atau prestasi kerja,tetapi juga mencakup bagaimana proses pekerjaan itu berlangsung. Menurut (Hasibuan, 2014) mengungkapkan bahwa "Kinerja merupakan gabungan tiga faktor penting, yaitu kemampuan dan minat seorang pekerja,kemampuan dan penerimaan atas penjelasan delegasi tugas dan peran serta tingkat motivasi pekerja. Sedangkan menurut (Mangkunegara, 2017), kinerja (performance) dipengaruhi oleh tiga faktor yaitu: faktor individu, faktor psikologi dan faktor organisasi. Dharma, (2004) mengungkapkan bahwa hampir semua pengukuran kinerja mempertimbangkan hal-hal 1) kuantitas, berkaitan dengan jumlah yang harus diselesaikan atau dicapai, 2) kualitas, berkaitan dengan mutu yang dihasilkan baik berupa kerapian kerja dan ketelitian kerja atau tigkat kesalahan yang dilakukan pegawai, dan 3) ketepatan waktu yaitu sesuai apa tidak dengan waktu yang direncanakan. Fadel, (2009) mengemukakan beberapa indikator yang digunakan untuk mengukur kinerja pegawai yaitu : 1). Pemahaman atas tupoksi. Bahwa harus terlebih dulu paham tentang tujuan pokok dan fungsi masing-masing serta mengerjakan tugas sesuai dengan apa yang menjadi tanggung jawabnya, 2). Inovasi. Memiliki inovasi yang posotif dan menyampaikan pada atasan serta mendiskusikannya pada rekan kerja tentang pekerjaan, 3) Kecepatan kerja. Dalam menjalankan tugas kecepatan kerja harus di perhatikan dengan menggunkan mengikuti metode kerja yang ada, 4) Keakuratan kerja. Tidak hanya cepat, namun dalam menyelasaikan tugas karyawan juga harus disiplin dalam mengerjakan tugas dan teliti dalam bekerja dan melakukan pengecekan ulang, dan 5) Kerjasama. Kemampuan dalam bekerja sama dengan rekan kerja lainya seperti bisa menghargai pendapat orang lain.

\section{Motivasi Kerja}

Motivasi berasal dari kata motove atau dengan bahasa latinnya yaitu movere, yang berarti “mengarahkan". Menurut Nawawi, (2011) kata motivasi (motivation) berasal dari kata dasar motive yang berarti dorongan sebab atau alasan seseorang melakukan sesuatu. Dengan demikian motivasi merupakan kondisi yang mendorong atau membuat seseorang melaksanakan kegiatan secara langsung dengan sadar. Menurut (Martoyo, 2000) bahwa manusia dalam aktivitas kebiasaannya melakukan sesuatu asalkan dapat menghasilkan sesuatu yang menganggap dirinya memiliki suatu nilai yang sangat berharga, yang tujuannya untuk melangsungkan kehidupannya, rasa tentram, rasa aman dan sebagainya. Buhler, (2004) menyatakan, motivasi pada dasarnya adalah proses yang menentukan seberapa banyak usaha yang akan diberikan untuk melaksanakan pekerjaan. Motivasi atau dorongan untuk bekerja ini sangat menentukan bagi tercapainya sesuatu tujuan, maka organisasi harus dapat menumbuhkan motivasi kerja setinggi-tingginya bagi para karyawan dalam perusahaan. Menurut (Samsuddin, 2009) mengemukakan bahwa motivasi adalah proses mempengaruhi atau mendorong dari luar terhadap seseorang atau kelompok kerja agar mereka mau melaksanakan sesuatu yang telah ditetapkan. Menurut (Samsuddin, 2009) menyatakan bahwa motivasi merupakan daya dorong bagi seseorang untuk memberikan kontribusi yang sebesar mungkin demi keberhasilan organisasi mencapai tujuannya."

Hasibuan, (2014) menyatakan bahwa motivasi kerja adalah daya kegairahan kerja yang diberikan kepada seseorang supaya mereka mau bekerja sama, bekerja efektif dan terintegrasi untuk mencapai kepuasan dengan segala daya upayanya. Motivasi kerja merupakan bagian faktor yang turut menentukan kinerja seseorang. Besar atau kecilnya motivasi berpengaruh pada kinerja seseorang dan tergantung pada seberapa banyak 
intensitas motivasi yang diberikan. Perbedaan motivasi kerja bagi pegawai biasanya tercermin dalam berbagai kegiatan dan prestasi yang dicapainya.

Menurut Soeroso, (2004) motivasi merupakan suatu proses psikologis yang memperlihatkan interaksi antara sikap, kebutuhan, persepsi, dan keputusan yang terjadi pada seseorang. Dan motivasi sebagai proses psikologis timbul dari faktor dalam diri orang-orang itu sendiri yang disebut faktorintrinsik atau faktor dari luar diri yang disebut factor ekstrinsik. Menurut Faustino dalam buku (Kadarisman, 2013) mengemukakan sebagai berikut motivasi seorang pekerja untuk bekerja biasanya merupakan hal yang rumit, karena motivasi ini melibatkan faktor-faktor individual dan faktor-faktor organisasional. Mangkunegara, (2017) menyatakan bahwa motivasi kerja dapat diukur melalui indikator sebagai berikut : 1) kerja keras, 2) orientasi masa depan, 3) tingkat cita-cita yang tinggi, 4) orientasi tugas/sasaran, 5) usaha untuk maju, 6) ketekunan, 7) rekan kerja, 8) pemanfaatan waktu.

\section{Promosi}

Promosi jabatan adalah perpindahan dari satu jabatan kejabatan lain yang mempunyai status dan tanggung jawab lebih tinggi dan biasannya disertai dengan peningkatan gaji atau upah lainnya. Adanya Promosi jabatan akan membuat karyawan termotivasi untuk bekerja lebih giat,bersemangat,disiplin, dan meningkatkan prestasi kerja, sehingga mencapai tujuan organisasi secara optimal. Menurut (Hasibuan, 2014) mengatakan bahwa promosi adalah yang memperbesar authority dan responsibility karyawan kejahatan yang lebih baik tinggi di dalam satu organisasi sehingga kewajiban,hak,status, dan penghasilannya semakin besar. Dessler, (2015) mengatakan "Dalam proses manajemen sumber daya manusia, proses promosi jabatan harus didahului dengan melihat spesifikasi jabatan yang akan diisi oleh karyawan di organisasi tersebut.

Dengan demikian promosi akan selalu diikuti oleh tugas, tangguang jawab dan wewenang yang lebih tinggi dan jabatan yang akan diduduki sebelumnya, selnjutnya promosi direalisasikan untuk memajukan pegawai. Untuk mencapai tujuan promosi maka hendaknya promosi jabatan dilakukan berdasarkan azas- azas promosi jabatan sebagaimana (Hasibuan, 2014) mengemukakan bahwa: 1) kepercayaan, 2) keadilan, dan 3) formasi. (Fathoni, 2006) mengemukakan bahwa indikator yang dapat dipromosikan antara lain: kejujuran, disiplin, prestasi kerja, kerja sama, kecakapan, loyalitas, kepemimpinan, komunikatif, dan pendidikan.

\section{Kepuasan Kerja}

Umar, (2011), menyatakan bahwa :Kepuasan kerja adalah perasaan dan penilaian seseorang atas pekerjaanya, khususnya mengenai kondisi kerjanya, dalam hubunganya dengan apakah pekerjaannya mampu memenuhi harapan, kebutuhan,dan keinginanya. Dari definisi-definisi diatas, dapat disimpulkan bahwa kepuasan kerja adalah keadaan psikis yang menyenangkan yang dirasakan oleh pekerja dalam suatu lingkungan pekerjaan karena terpenuhinya kebutuhan secara memadai. Menurut Hasibuan, (2011) mendifinisikan bahwa, kepuasan kerja adalah sikap emosional yang menyenangkan dan mencintai pekerjaannya. Sikap ini dicerminkan oleh moral kerja. Sunyoto, (2012) mendifinisikan kepuasan kerja sebagai sifat individual seseorang sehingga memiliki tingkat kepuasan yang berbeda sesuai dengan sistem nilai-nilai yang berlaku pada dirinya. Hal ini disebabkan oleh adanya perbedaan pada masing-masing individu.Semakin banyak aspek-aspek dalam pekerjaan sesuai dengan keinginan individu tersebut maka semakin tinggi tingkat kepuasan yang dirasakan begitu pula sebaliknya. Menurut (Mathis \& Jackson, 2011) kepuasan kerja adalah keadaan emosi yang positif dan mengealuasi pengalaman kerja seseorang. Ketidakpuasan kerja muncul saat 
harapam-harapan ini tidak terpenuhi. Kepuasan kerja mempunyai banyak dimensi, secara umum adalah kepuasan dalam pekerjaan itu sendiri, gaji, pengakuan, hubungan antara supervisor dengan tenaga kerja, dan kesempatan untuk maju. Faktor-faktor yang mempengaruhi kepuasan kerja (Sutrisno, 2010: 80), yaitu: 1) faktor psikologis, merupakan faktor yang berhubungan dengan kejiwaan karyawan,yang meliputi minat, ketentraman dalam kerja, sikap terhadap kerja, bakat, dan keterampilan, 2) faktor sosial, merupakan faktor yang berhubungan dengan interaksi sosial antar karyawan dengan atasan, 3) faktor fisik, merupakan faktor yang berhubungan dengan kondisi fisik karyawan, meliputi jenis pekerjaan, pengaturan waktu dan waktu istirahat, perlengkapan pekerjaan, keadaan ruangan, suhu, penerangan, pertukaran udara, kondisi kesehatan karyawan, umur dan sebagainya, dan 4) faktor finansial, merupakan fator yang berhubungan jaminan serta kesejahteraan karyawan, yang meliputi sistem dan gaji, jaminan sosial, macam-macam tunjangan, fasilitas yang diberikan, promosi, dan sebagainya. Hasibuan, (2014) menyatakan bahwa indikator kepuasan kerja yaitu 1) menyenangi pekerjaanya, yaitu seseorang menyenangi pekerjaanya karena ia bisa mengerjakanya, 2) mencintai pekerjaanya, 3) moral kerja, yaitu kesepakatan batinlah yang muncul dari dalam diri seseorang atau sekolompok orang untuk mencapai tujuan tertentu sesuai dengan mutu yang di tetapkan, 4) kedisiplinan, yaitu kondisi yang tercipta dan terbentuk melalui proses dari serangkaian perilaku yang menunjukan nilai-nilai ketaatan, kepatuhan, kesetiaan, keteraturan dan ketertiban, dan 5) prestasi kerja, yaitu hasil kerja yang dicapai seseorang dalam melaksanakan tugas-tugas yang dibebankan kepadanya yang didasarkan atas kecakapan dan kesunguhan serta waktu.

Widodo, (2015) menyatakan bahwa ada beberapa indikator dari kepuasan kerja,yaitu: 1) gaji, yaitu jumlah bayaran yang diterima seseorang akibat dari pelaksanaan keja apakah sesuai dengan kebutuhan dan dirasakan adil, 2) pekerjaan itu sendiri, yaitu isi pekerjaan yang dilakukan seseorang apakah memiliki elemen yang memuaskan, 3) rekan kerja, yaitu teman-teman kepada siapa seseorang senantiasa berinteraksi dalam pelaksanaan pekerjaan. Seseorang dapat merasakan rekan kerjanya sangat menyenangkan atau tidak menyenangkan, 4) atasan, yaitu seseorang senantiasa memberi perintah atau petunjuk dalam pelaksanaan kerja. Cara-cara kerja atasan dapat tidak menyenagkan bagi seseorang atau menyenangkan dan hal ini dapat mempengaruhi kepuasan kerja, 5) promosi, yaitu kemungkinan seseorang dapat berkembang melalui kenaikan jabatan, seseorang dapat merasakan adanyakemungkinan besar untuk naik jabatan atau tidak. Ini juga dapat mempengaruhi tingkat kepuasan kerja seseorang, dan 6) lingkungan kerja yang, yaitu lingkungan fisik dan psikologis.

\section{METODE PENELITIAN}

Pendekatan yang digunakan adalah deskripsi kuantitatif ( penelitian yang menggunakan angka, mulai dari pengumpulan data, penafsiran terhadap data, serta penampilan hasilnya ).dan merupakan penelitian terhadap masalah-masalah yang diteliti, berupa fakta-fakta saat ini dari suatu populasi. Populasi pada penelitian ini adalah seluruh pegawai staf yang bekerja pada Dinas Kesehatan Kabupaten Aceh Tamiang yang berjumlah 55 orang. Penelitian ini menggunakan sampel jenuh, dimana semua populasi dijadikan sampel. Teknik pengumpulan data dilakukan dengan daftar pertanyaan (kuesioner), wawancara (interview) dan studi dokumentasi. Sebelum melakukan pengujian hipotesis dari penelitian ini, terlebih dahulu dilakukan pengujian asumsi klasik untuk memastikan bahwa alat uji regresi berganda dapat digunakan atau tidak dalam penelitian. Apabila uji asumsi klasik telah terpenuhi, maka alat uji statistik regreai linier berganda dapat pergunakan. Analisis data menggunakan analisis regresi linier berganda. 


\section{HASIL DAN PEMBAHASAN}

\section{Uji Asumsi Klasik}

\section{Uji Normalitas}

Uji normalitas bertujuan untuk menguji apakah dalam model regresi, variabel pengganggu atau residual memiliki distribusi normal, ada dua cara mendeteksi apakah residual berdistribusi normal atau tidak yaitu dengan uji statistik dan analisa grafik.

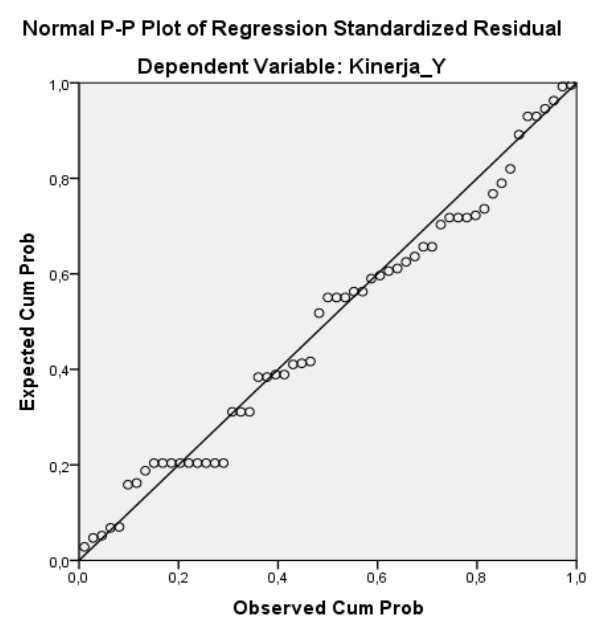

Gambar 1. Hasil Uji Normalitas P-Plot

Berdasarkan pada grafik histogram, residual data telah menunjukkan kurva normal yang membentuk lonceng sempurrna (Juliandi, Irfan, \& Manurung, 2015). Kemudian, pada grafik normal P-P Plot data menyebar di sekitar garis diagonal. Dengan demikian, residual data berdistribusi normal dan model regresi sudah memenuhi asumsi normalitas.

\section{Uji Multikolinearitas}

Uji Multikolinieritas bertujuan untuk menguji apakah model regresi ditemukan adanya kolerasi antar variabel bebas. Model regresi yang baik seharusnya tidak terjadi kolerasi di antara variabel independen. Hasil uji multikolinieritas dapat dilihat pada tabel berikut ini:

Tabel 1. Hasil Uji Multikolinearitas

\begin{tabular}{ccc}
\hline \multirow{2}{*}{ Model } & \multicolumn{2}{c}{ Collinearity Statistics } \\
\cline { 2 - 3 } & Tolerance & VIF \\
\hline (Constant) & & \\
\hline Motivasi_Kerja_X1 &, 199 & 5,026 \\
\hline Promosi_X2 &, 169 & 5,932 \\
\hline Kepuasan_Kerja_X3 &, 500 & 1,999 \\
\hline
\end{tabular}

Berdasarkan tabel 4.6 dapat diketahui hasil perhitungan tolerance menunjukkan bahwa Motivasi Kerja $\left(\mathrm{X}_{1}\right)$ memiliki nilai tolerance 0,199 , Promosi $\left(\mathrm{X}_{2}\right)$ memiliki nilai tolerance 0,169, dan Kepuasan Kerja memiliki nilai tolerance 0,500. Ketiga nilai tersebut lebih besar dari 0,10 yang artinya tidak ada korelasi antara variabel bebas. Kemudian, hasil perhitungan nilai Varian Inflation Factor (VIF) menunjukkan bahwa Motivasi Kerja $\left(\mathrm{X}_{1}\right)$ memiliki nilai VIF 5,026, Promosi $\left(\mathrm{X}_{2}\right)$ memiliki nilaiVIF 5,932, dan Kepuasan Kerja memiliki nilai VIF 1,999. Ketiga nilai variabel tersebut $<10$. Jadi, dapat disimpulkan bahwa tidak ada multikolinieritas antar variabel bebas dalam model regresi. 


\section{Uji Heteroskedastisitas}

Uji Heteroskedastisitas bertujuan untuk menguji apakah dalam model regresi terjadi ketidaksamaan variance dari residual satu pengamatan ke pengamatan yang lain.

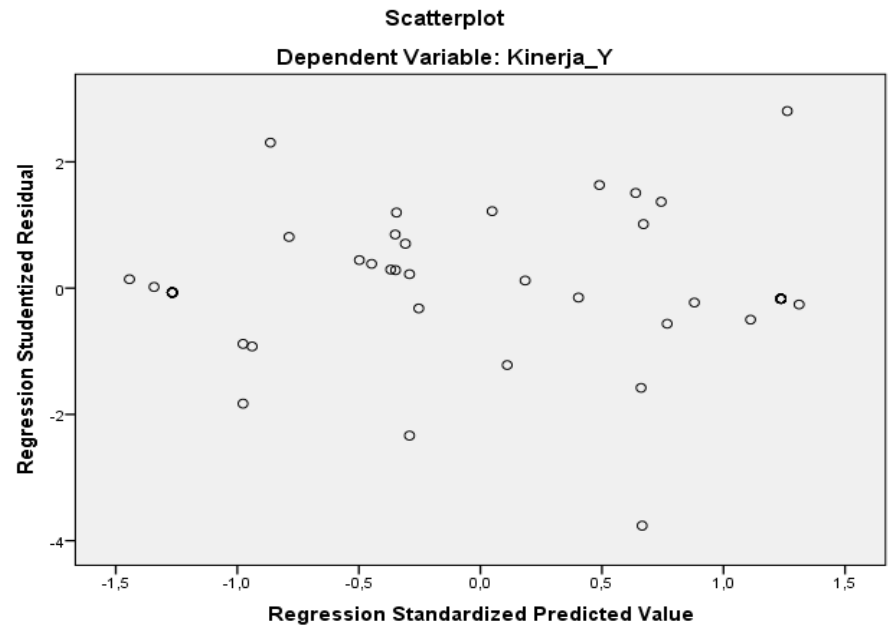

Gambar 3. Hasil Uji Heteroskedastisitas.

Berdasarkan gambar 3 terlihat bahwa titik menyebar di atas dan dibawah atau disekitar angka 0.Titik-titik tidak mengumpul hanya di atas atau di bawah saja.Penyebaran titik-titik data tidak membentuk pola.Dengan demikian dapat disimpulkan bahwa tidak terjadi masalah heteroskedastisitas sehingga model regresi yang baik dan ideal dapat terpenuhi.

\section{Regresi Linear Berganda}

Analisis Regresi Linier Berganda digunakan untuk menganalisa pengaruh beberapa variabel independen $(\mathrm{X})$ terhadap satu variabel dependen $(\mathrm{Y})$ secara bersama-sama yaitu sebagai berikut:

Tabel 2. Hasil Uji Koefesien Regresi

\begin{tabular}{|c|c|c|c|}
\hline \multirow{2}{*}{\multicolumn{2}{|c|}{ Model }} & \multicolumn{2}{|c|}{ Unstandardized Coefficients } \\
\hline & & $\mathrm{B}$ & Std. Error \\
\hline \multirow{4}{*}{1} & (Constant) & 17,288 & 2,710 \\
\hline & Motivasi_Kerja_X1 & ,346 &, 136 \\
\hline & Promosi_X2 & ,218 &, 146 \\
\hline & Kepuasan_Kerja_ &,- 092 & 121 \\
\hline
\end{tabular}

a. Dependent Variable: Kinerja_Y

Berdasarkan tabel 3 dapat disimpulkan bahwa persamaan di atas menunjukkan pengaruh masing-masing variabel independen (X) terhadap variabel dependen (Y). Hasil yang diperoleh dari uji regresi berganda adalah sebagai berikut:

$\mathrm{Y}=17,288+0,346 \mathrm{X}_{1}+0,218 \mathrm{X}_{2}-0,092 \mathrm{X}_{3}$

Berdasarkan Tabel 3 terlihat bahwa nilai konstanta sebesar 17,288 artinya, jika $\mathrm{X}_{1}, \mathrm{X}_{2}$, dan $\mathrm{X}_{3}$ nilainya sebesar 0 , maka variable $\mathrm{Y}$ memiliki nilai sebesar 17,288. Koefisien regresi variabel $\mathrm{X}_{1}$ sebesar 0,346 artinya jika variabel bebas lain nilainya tetap dan $\mathrm{X}_{1}$ mengalami kenaikan sebanyak 1\%, maka Y akan mengalami kenaikan sebesar 0,346. Koefisien bernilai positif artinya terjadi hubungan yang positif antara motivasi kerja terhadap kinerja pegawai. Koefisien regresi variabel $\mathrm{X}_{2}$ sebesar 0,218 artinya jika variabel bebas lain nilainya tetap dan $\mathrm{X}_{2}$ mengalami kenaikan sebanyak $1 \%$, maka $\mathrm{Y}$ akan mengalami kenaikan sebesar 0,218. Koefisien bernilai positif artinya terjadi hubungan positif antara promosi terhadap kinerja pegawai.Koefisien regresi variabel $\mathrm{X}_{3}$ sebesar 0,092 artinya jika variabel bebas lain nilainya tetap dan $\mathrm{X}_{3}$ mengalami kenaikan sebanyak 1\%, maka Y akan mengalami kenaikan sebesar 
0,092. Koefisien bernilai negatif artinya tidak terjadi hubungan antara kepuasan kerja terhadap kinerja pegawai.

\section{Uji Hipotesis}

\section{Uji Secara Parsial (Uji t)}

Hasil uji hipotesis secara parsial dapat dilihat pada tabel berikut ini

\begin{tabular}{llrr}
\multicolumn{4}{c}{ Tabel 4. Hasil Uji Parsial } \\
\hline \multicolumn{1}{c}{ Model } & Sig. \\
& & \\
\hline & & 6,379 &, 000 \\
\cline { 2 - 4 } 1 & Monstant) & 2,552 &, 014 \\
\cline { 2 - 4 } & Promasi_Kerja_X1 & 1,492 &, 142 \\
\cline { 2 - 4 } & Kepuasan_K2 &,- 763 &, 449 \\
\hline a. Dependent Variable: Kinerja Y & &
\end{tabular}

Uji parsial (uji t) ini bertujuan untuk mengetahui seberapa jauh pengaruh variabel independen secara parsial terhadap variabel dependen. Dari tabel 4 di atas diketahui bahwa nilai $t_{\text {hitung }}$ untuk variabel Motivasi Kerja (X1) adalah 2,552 lebih besar dari $t_{\text {tabel }} 1,675$ dengan nilai sig $0,014>0,05$. Hal ini berarti variabel motivasi kerja secara parsial berpengaruh positif tetapi tidak signifikan terhadap variabel kinerja karyawan. Nilai $t_{\text {hitung }}$ berdasarkan tabel 4 untuk variabel Promosi (X2) adalah 1,492 lebih kecil dari tabel 1,675 dengan nilai sig 0,142>0,05. Hal ini berarti variabel promosi secara parsial berpengaruh positif tetapi tidak signifikan terhadap variabel kinerja karyawan. Nilai $t_{\text {hitung }}$ untuk variabel Kepuasan Kerja (X3) adalah $-0,763$ lebih besar dari $t_{\text {tabel-1, }} 1,675$ dengan nilai sig $0,449>0,05$. Hal ini berarti variabel kepuasan kerja secara parsial berpengaruh secara positif tetapi tidak signifikan terhadap variabel kinerja karyawan.

\section{Uji Simultan Signifikan (Uji F)}

Hasil pengujian hipotesis secara serempak dapat dilihat pada tabel 5yaitu sebagai berikut:

Tabel 5. Hasil Uji Parsial

\begin{tabular}{llrrrrr} 
& Model & Sum of Squares & Df & Mean Square & $F$ & Sig. \\
\hline & Regression & 332,254 & 3 & 110,751 & 23,624 &, $000^{\circ}$ \\
\cline { 2 - 7 } & Residual & 239,092 & 51 & 4,688 & & \\
\cline { 2 - 7 } & Total & 571,345 & 54 & & &
\end{tabular}

a. Dependent Variable: Kinerja_Y

b. Predictors: (Constant), Kepuasan_Kerja_X3, Motivasi_Kerja_X1, Promosi_X2

Rumus untuk mencari $\mathrm{F}$ tabel adalah $\mathrm{n}-\mathrm{k}-1=55-3-1=51$ sehingga nilai $\mathrm{F}_{\text {tabel }}$ adalah 2,55. Berdasarkan tabel 5 diperoleh bahwa $\mathrm{F}_{\text {hitung }}$ 23,624 lebih besar dibandingkan dengan nilai $F_{\text {tabel }}$ 2,55 dan nilai signifikasi 0,000 lebih kecil dari 0,05. Hal ini mengindikasikan bahwa hasil penelitian menolak $\mathrm{H}_{0}$. Dengan demikian secara serempak motivasi kerja, promosi, dan kepuasan kerja berpengaruh positif dan signifikan terhadap kinerja karyawan.

\section{Koefisien Determinasi $\left(\mathbf{R}^{2}\right)$}

Nilai koefesien determinasi dipergunakan untuk mengetahui kemampuan variabel bebas dalam menjelaskan variasi dari variabel terikat.

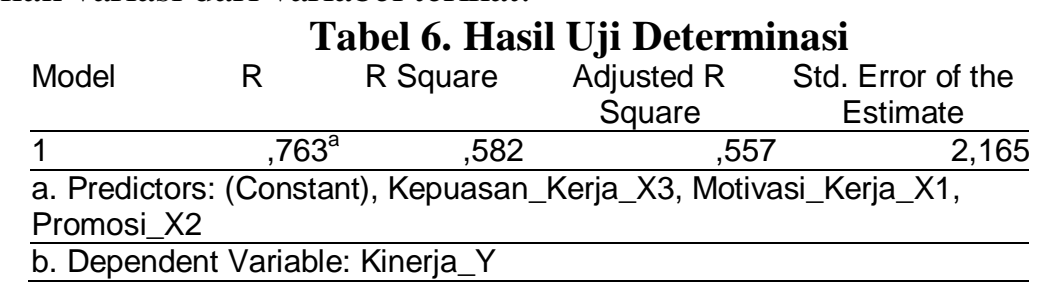


Besarnya angka $\mathrm{R}$ square $\left(\mathrm{R}^{2}\right)$ adalah 0,582. Angka tersebut dapat digunakan untuk melihat pengaruh motivasi kerja, promosi, dan kepuasan kerja secara gabungan terhadap kinerja dengan cara menghitung Koefisien Determinasi (KD) dengan menggunakan rumus sebagai berikut:

$$
\begin{aligned}
& D=R^{2} \times 100 \% \\
& D=0,582 \times 100 \% \\
& D=58,2 \%
\end{aligned}
$$

Angka tersebut mempunyai maksud bahwa pengaruh motivasi kerja, promosi, dan kepuasan kerja secara gabungan terhadap kinerja adalah 58,2\%. Adapun sisanya sebesar 41,8 (100\% - 58,2\%) dipengaruhi faktor lain. Dengan kata lain, variabilitas kinerja yang dapat diterangkan dengan menggunakan variabel motivasi kerja, promosi, dan kepuasan kerja adalah sebesar $58,2 \%$, sedangkan pengaruh sebesar $41,8 \%$ disebabkan oleh variabel-variabel lain di luar model ini.

\section{Pembahasan}

\section{Pengaruh Motivasi terhadap Kinerja Pegawai}

Berdasarkan hasil pengolahan data yang diperoleh diketahui bahwa variabel motivasi berpengaruh positif dan signifikan terhadap kinerja pegawai pada Dinas Kesehatan Kabupaten Aceh Tamiang. Hal ini berarti semakin tinggi motivasi kerja pegawai maka akan mampu meningkatkan kinerja pegawai. Menurut (Sembiring, 2012) menyebutkan bahwa, motivasi mengacu ke sistem makna bersama yang dianut oleh anggota-anggota yang membedakan organisasi itu dari organisasi-organisasi lain. Namun apabila motivasi tidak memiliki pedoman dan kejelasan sanksi bagi pelanggar aturan, dapat mengakibatkan pegawai bertindak semaunya sendiri, hal ini membuat pegawai tidak takut melanggar aturan yang ada.

Hasil penelitian ini sejalan dengan penelitian terdahulu yang dilakukan oleh (Susanty \& Baskoro, 2012) yang menyatakan bahwa untuk menciptakan pimpinan yang bijaksana dan adil, para pemimpin harus dapat memberi teladan yang baik kepada bawahan. Salah satu contoh teladan yang baik dari pimpinan adalah tiba dikantor tepat waktu sehingga bawahan akan merasa malu jika mereka tiba terlambat. Perlunya pemimpin melakukan pengawasan dan memberikan pemahaman terhadap sebagian kecil pegawai tersebut agar bisa bekerja secara mandiri dan tetap berdisiplin dan berinisiatif baik ada atau tidak ada pimpinan ditempat. Sehingga penyelesaian tugas dan tanggung jawab yang diemban mampu berjalan dengan baik dan selesai pada waktu yang ditentukan. Kemudian perlunya pimpinan merubah paradigma tersebut sehingga motivasi yang disediakan oleh Organisasi benar-benar dapat dilaksanakan dengan sebaik-baiknya Sehingga akan memperbaiki kinerja pegawai. Hasil penelitian sejalan dengan hasil penelitian (Jufrizen, 2018); (Jufrizen \& Pulungan, 2017) dan (Jufrizen, 2018) yang menunjukkan bahwa motivasi kerja berpengaruh signifikan terhadap kinerja pegawai.

\section{Pengaruh Promosi Terhadap Kinerja Pegawai}

Berdasarkan hasil pengolahan data diperoleh bahwa variabel promosi berpengaruh tidak berpengaruh signifikan terhadap kinerja pegawai pada Dinas Kesehatan Kabupaten Aceh Tamiang. Hasl ini berarti bahwa promosi yang dilaksanakan tidak memberikan dampak terhadap kinerja pegawai. Hasil penelitian (Susanty \& Baskoro, 2012) menjelaskan bahwa untuk menumbuhkan motivasi kerja karyawan perlu menciptakan suasana kerja yang harmonis karena suasanan kerja yang harmonis akan mendorong karyawan untuk lebih semangat dalam bekerja. Suasana kerja yang harmonis dpat diciptakan melalui pembagian beban kerja yang seimbang antar karyawan, sehuingga tidak ada kesenjangan antar pegawai, Suasana kerja yang harmonis juga dapat diciptakan melalui komunikasi yang baik. Salah satu hal yang seringkali 
dilupakan oleh pimpinan adalah cara melakukan komunikasi dengan bawahan. Pimpinan sebaiknya melakukan komunikasi dengan bawahan dengan menggunakan bahasa dan nada lebih halus sehingga bawahan merasa lebih dihargai oleh organisasi. Cara berkomunikasi dengan bawahan dengan menggunakan bahasa dan nada yang keras hanya akan menumbulkan rasa benci. Dalam Promosi perlunya pimpinan perusahaan memperhatikan pemenuhan spesifikasi ke butuhan sesuai dengan keinginan pegawai yang konsistensi, sehingga promosi dapat dijalankan dengan sebaik-baiknya dan dapat mencapai objektif yang diinginkan oleh semua pihak yang terlibat dalam dinas tersebut. Dan dapat dimanfaatkan benar-benar untuk memperbaiki produktivitas kerja di dinas dan ke masyarakat. Hasil penelitian tidak sejalan dengan hasil penelitian (Syahputra \& Jufrizen, 2019) yang berkesimpulan bahwa promosi berpengaruh signifikan terhadap kinerja.

\section{Pengaruh Kepuasan Kerja Terhadap Kinerja Pegawai}

Berdasarkan hasil penelitian diketahui bahwa variabel kepuasan kerja tidak berpengaruh signifikan terhadap kinerja pegawai. Hal ini mengindikasikan bahwa kepuasan kerja karyawan bukanlah salah satu faktor yang mampu meningkatkan kinerja pegawai. Secara teori disebutkan bahwa salah satu faktor pendorong yang menyebabkan manusia bekerja adalah karena memiliki kebutuhanyang harus dipenuhi, yang pemunculannya sangat tergantung dari kepentingan individu. Salah satu teori yang dapat dipergunakan untuk memotivasi pegawai dalam bekerja. Seorang pegawai akan merasa nyaman dan tinggi loyalitasnya pada organisasi apabila memperoleh kepuasan kerja sesuai dengan apa yang diinginkan serta mendapatkan tambahan penghasilan sesuai dengan tanggung jawab yang di laksanakan. Kepuasan kerja mencerminkan perasaan seseorang terhadap pekerjaannya dan ini nampak pada perilaku dan sikap pegawai dalam kehidupan sehari-hari, biasanya ditunjukkan dalam hal tanggapan yang positif dalam bekerja. Perlu disadari bahwa kepuasan kerja merupakan faktor yang mendorong pegawai/karyawan lebih giat bekerja dan sekaligus sebagai motivasi dalam bekerja. Dengan demikian dapat disimpulkan bahwa faktor kepuasan kerja berpengaruh signifikan terhadap kinerja pegawai pada Dinas Kesehatan Kabupaten Aceh Taming. Hasil ini didukung oleh penelitian sebelumnya yang dilakukan oleh (Munparidi, 2012) yang menyatakan bahwa variabel kepuasan kerja dan lingkungan kerja mempunyai pengaruh positip dan siginifikan terhadap kinerja pegawai. Dengan kata lain kepuasan kerja mampu menentukan profesionalisme kinerja pegawai. Karena kepuasan kerja berdasarkan penelitian ini sangat berpengaruh pada pembentukan kinerja pegawai pada Dinas Kesehatan Kabupaten Aceh Tamiang seharusnya memberikan kepuasan kerja yang sesuai dengan kebutuhan kerja pegawai, Untuk mengatasinya hal ini maka kepuasan kerja harus didasarkan pada analisis kepuasan kerja.

Hasil pengujian hipotesis dalam penelitian ini juga turut membuktikan pendapat (Gibson, Ivancevich, \& Donnely, 2008) menggambarkan hubungan timbal balik antara kepuasan dan kinerja. Di satu sisi dikatakan kepuasan kerja menyebabkan peningkatan kinerja sehingga pekerja yang puas akan lebih produktif, di sisi lain terjadi kepuasan kerja disebabkan oleh adanya kinerja sehingga pekerja yang lebih produktif akan mendapatkan kepuasan. Hasil penelitian tidak sejalan dengan dengan (Robbins \& Judge, 2008) menggambarkan bahwa kepuasan kerja adalah sikap umum terhadap pekerjaan seseorang, yang menunjukkan perbedaan antara jumlah penghargaan yang diterima pekerja dan jumlah yang mereka yakini seharusnya mereka terima. Hasil diatas sejalan dengan hasil penelitian sebelumnya yang dilakukan oleh (Jufrizen, 2016) yang menyimpulkan bahwa adalah variabel motivasi, kepuasan kerja dan komitmen organisasi berpengaruh signifikan terhadap kinerja. Hasil penelitian (Jufrizen, Gultom, Sitorus, Sari, \& Nasution, 2018); (Ainanur \& Tirtayasa, 2018); (Jufrizen, 
Lumbanraja, Salim, \& Gultom, 2017) dan (Syahputra \& Jufrizen, 2019) menunjukkan bahwa kepuasan kerja berpengaruh signifikan terhadap kinerja karyawan.

\section{Pengaruh Motivasi, Promosi, dan Kepuasan kerja Terhadap Kinerja Pegawai}

Berdasarkan hasil penguji secara serempak, diketahui bahwa motivasi, promosi dan kepuasan kerja berpengaruh signifikan terhadap kinerja pegawai pada Dinas Kesehatan Kabupaten Aceh Tamiang. Hal ini menunjukkan bahwa motivasi.promosi dan Kepuasan kerja sangat menentukan dalam peningkatan kerja pegawai pada Dinas Kesehatan kabupaten Aceh Tamiang.Artinya sebaiknya senantiasa memperhatikan kinerja pegawai dengan motivasi yang baik,pemberian promosi kepada pegawai dan kepuasan kerja yang bermanfaat pada pegawai, sehingga dapat meningkatkan kinerja pegawai pada Dinas Kesehatan kabupaten Aceh Tamiang. Untuk memenuhi kebutuhan tersebut diatas, motivasi menjadi sangat penting guna mendorong terciptanya kinerja pegawai yang baik para pegawai sebagai aset sumber aset sumber daya agar dapatbekerja sesuai dengan arah dan kebijakan. Apabila promosi diartikan merupakan upaya pribadi seorang pegawai untuk mencapai suatu sermangat kerja. Dimana peran promosi sangat penting bagi Dinas untuk meningkatkan kemapuan teknis,teoritis,konseptual, dan moral pegawai sesuai dengan kebutuhan pekerjaan/jabatan, Maka promosi sebaiknya dijadikan dasar munculnya semangat baru untuk memperbaiki kinerja pegawai yang baik dan mampu menggerakkan aktivitas orgnisasi untuk bisa lebih berkembang lagi secara konsisten dan baik. Selain itu usaha yang dilakukan pegawai baik itu besar atau kecil, apabila didasari dengan kesungguhan dan loyalitas maka akan menghasilkan suatu nilai atau usaha tersebut yang dinamakan kepuasan kerja.

\section{KESIMPULAN}

Berdasarkan hasil analisis yang telah dibahas pada bab terdahulu, maka dapat ditarik kesimpulan bahwa Secara parsial, motivasi kerja berpengaruh signifikan terhadap kinerja pegawai di Dinas Kesehatan Kabupaten Aceh Tamiang. Secara parsial, promosi jabatan tidak berpengaruh signifikan terhadap kinerja pegawai di Dinas Kesehatan Kabupaten Aceh Tamiang. Secara parsial kepuasan kerja tidak berpengaruh signifikan terhadap kinerja pegawai Dinas kesehatan Kabupaten Aceh Tamiang. Secara simultan, motivasi, promosi, dan kepuasan kerja berpengaruh signfikan terhadap kinerja pegawai di Dinas Kesehatan Kabupaten Aceh Tamiang. Berdasarkan hasil penelitian penulis memberikan beberapa saran kepada Dinas kesehatan Kabupaten Aceh Tamiang yaitu lebih memperkuat motivasi yang dapat memberikan contoh tauladan terhadap pegawainya dan pimpinan dapat memberikan pemahaman yang jelas terhadap pegawai agar bekerja secara jujur dan benar-benar mematuhi peraturan yang ada sehingga dalam setiap menjalankan tugas-tugasnya pegawai mampu bekerja maksimal.Selain itu pegawai diharapkan memiliki inisiatif ,tidak hanya bergantung kepada keberadaan pimpinan. Pimpinan dapat memberikan motivasi pegawainya sehingga berpengaruh terhadap kinerja dan profesoinalitas kerja, prestasi, jenjang, karir dan syarat lainnya, sehingga pekerjaan dapat berjalan secara sistematis. Menampung aspirasi tentang semua keluhan dan kesulitan yang sering dihadapi pegawai dalam melaksanakan tugasnya dan melakukan musyawarah secara bersama-sama demi meningkatkan kinerja agar dapat mencapai target yang ditetapkan organisasi.memperbaiki kekurangan -kekurangan dalam sistemtis pekerjaan, baik berhubungan dengan motivasi, promosi, kepuasan kerja sehingga berpengaruh untuk meningkatkan kinerja yang baik agar pekerjaan secara keseluruhan terlaksana dengan sebaik-baiknya. Dengan semakin baiknya kinerja pegawai maka hasil yang dicapai organisasi akan lebih baik dimasa yang akan datang, sekaligus meningkatkan pelayanan kepada masyarakat. 


\section{DAFTAR PUSTAKA}

Ainanur, A., \& Tirtayasa, S. (2018). Pengaruh Budaya Organisasi, Kompetensi dan Motivasi Terhadap Kinerja Karyawan. Maneggio: Jurnal Ilmiah Magister Manajemen, 1(1), 1-14. https://doi.org/10.30596/maneggio.v1i1.2234

Arianty, N., Bahagia, R., Lubis, A. A., \& Siswadi, Y. (2016). Manajemen Sumber Daya Manusia. Medan: Perdana Publishing.

Buhler, P. (2004). Alpa Teach Yourself. Management Skills dalam 24 Jam. Jakarta: Prenada Media.

Dessler, G. (2015). Manajemen Sumber Daya Manusia (14th ed.). Jakarta: Salemba Empat.

Dharma, A. (2004). Manajemen Supervisi. Jakarta: PT Raja Grafindo Persada.

Fadel, M. (2009). Reinventing local government: pengalaman dari daerah. (R. L. Toruan, Ed.). Jakarta: PT Elek Media Komputindo.

Fathoni, A. (2006). Organisasi dan Manajemen Sumber Daya Manusia. Jakarta: PT Rineka Cipta.

Gibson, J. L., Ivancevich, J. M., \& Donnely, J. H. (2008). Organisasi, Perilaku, Struktur dan Proses. Jakarta: Binarupa Aksara.

Hasibuan, M. S. . (2014). Manajemen Sumber Daya Manusia. Jakarta: Bumi Aksara.

Hasibuan, M. S. P. (2011). Manajemen Sumber Daya Manusia. Edisi Revisi Jakarta: Bumi Aksara. Jakarta: Bumi Aksara.

Jufrizen, J. (2016). Efek Mediasi Kepuasan Kerja Pada Pengaruh Kompensasi Terhadap Kinerja Karyawan. Jurnal Ilmiah Manajemen Dan Bisnis, 17(1).

Jufrizen, J. (2018). Peran Motivasi Kerja dalam Memoderasi Pengaruh Kompensasi dan Disiplin Kerja terhadap Kinerja Karyawan. In Prosiding: The National Conferences Management and Business (NCMAB) 2018 (pp. 405-424).

Jufrizen, J., Gultom, D. K., Sitorus, S. A., Sari, M., \& Nasution, M. I. (2018). The Effect of Organizational Culture and Islamic Work Ethic on Permanent Lecturers' Job Satisfaction, Organizational Commitment And Work Performance at Private Islamic Universities in the City of Medan. In Proceeding 1st International Conference of Economic Studies (ICOES) 2018 (pp. 179-186).

Jufrizen, J., Lumbanraja, P., Salim, S. R. A., \& Gultom, P. (2017). The Effect of Compensation, Organizational Culture and Islamic Work Ethic Towards the Job Satisfaction and the Impact on the Permanent Lecturers. International Business Management, 11(1), 53-60.

Jufrizen, J., \& Pulungan, D. R. (2017). Implementation of Incentive and Career Development of Performance with Motivation as an Intervening Variable. In Proceedings of AICS-Social Sciences (pp. 441-446).

Juliandi, A., Irfan, \& Manurung, S. (2015). Metodologi Penelitian Bisnis Konsep dan Aplikasi. Medan: UMSU Press.

Kadarisman, M. (2013). Manajemen Pengembangan Sumber Daya Manusia. Jakarta: PT Raja Grafindo Persada.

Mangkunegara, A. A. P. (2017). Manajemen Sumber Daya Manusia (Bandung). Remaja Rosdakarya.

Martoyo, S. (2000). Manajemen Sumber Daya Manusia. Yogyakarta: BPFE.

Mathis, R. L., \& Jackson, J. H. (2011). Human Resource Management = Manajemen Sumber Daya Manusia. Jakarta: Salemba Empat.

Moeheriono, M. (2014). Pengukuran Kinerja Berbasis Kompetensi (Revisi). Jakarta: PT Raja Grafindo Persada. 
Mujiatun, S., Jufrizen, J., \& Ritonga, P. (2019). Model Kelelahan Emosional: Antaseden Dan Dampaknya Terhadap Kepuasan Kerja Dan Komitmen Organisasi Dosen. MIX: Jurnal Ilmiah Manajemen, 9(3), 447-465.

Munparidi, M. (2012). Pengaruh Kepemimpinan, Motivasi, Pelatihan dan Lingkungan Kerja terhadap Kinerja Karyawan pada Perusahaan Daerah Air Minum Tirta Musi Kota Palembang. Orasi Bisnis : Jurnal Ilmiah Administrasi Niaga, 7(1), 47-54.

Nawawi, H. (2011). Manajemen Sumber Daya Manusia: Untuk Bisnis Yang Kompetitif. Yogyakarta: UGM Press.

Robbins, S. P., \& Judge, T. A. (2008). Perilaku Organisasi. Jakarta: Salemba Empat.

Samsuddin, S. (2009). Manajemen Sumber Daya Manusia. Bandung: Pustaka Setia.

Sembiring, M. (2012). Budaya dan Kinerja Organisasi. Bandung: Fokusmedia.

Soeroso, S. (2004). Manajemen Sumber Daya Manusiadi Rumah Sakit; Suatu Pendekatan Sistem. Jakarta: Penerbit Buku Kedokteran EGC.

Sunyoto, D. (2012). Manajemen Sumber Daya Manusia. Jakarta: PT Buku Seru.

Suradinata, E. (1996). Manajemen Sumber Daya Manusia. Bandung: Ramadan.

Susanty, A., \& Baskoro, S. W. (2012). Pengaruh Motivasi Kerja dan Gaya Kepemimpinan Terhadap Disiplin Kerja Serta Dampaknya Pada Kinerja Karyawan (Studi Kasus Pada PT. PLN (Persero) APD Semarang). J@TI Undip, 7(2), 77-84.

Sutrisno, E. (2012). Manajemen Sumber Daya Manusia. Jakarta: Kencana Prenada Media Group.

Syahputra, I., \& Jufrizen, J. (2019). Pengaruh Diklat, Promosi, Dan Kepuasan Kerja Terhadap Kinerja Pegawai. Maneggio: Jurnal Ilmiah Magister Manajemen, 2(1), 104-116. https://doi.org/10.30596/maneggio.v2i1.3364

Tika, M. P. (2014). Budaya Organisasi dan Peningkatan Kinerja Perusahaan (6th ed.). Jakarta: Bumi Aksara.

Umar, H. (2011). Riset Sumber Daya Manusia Dalam Organisasi. Jakarta: PT. Gramedia Pustaka Utama.

Wibowo. (2013). Manajemen Kinerja. Jakarta: Rajawali Pers.

Widodo, S. E. (2015). Manajemen Pengembangan Sumber Daya Manusia. Yogyakarta: Pustaka Pelajar.

Wirawan, W. (2009). Budaya dan Iklim Organisasi. Jakarta: Salemba Empat. 